\section{Field Assessment of Macronutrients and Nitrogen in Apple Leaves Using a Chlorophyll Meter}

\author{
Youngsuk Lee ${ }^{1}$, Hun Joong Kweon, Moo-Yong Park, and \\ Dongyong Lee
}

ADDITIONAL INDEX WORDs. field measurements, nutrient profiles, growing season, trees, fertilization, chlorophyll, regression modeling

SUMMARY. Nutrient content assessment of plant tissues is widely performed by farmers to determine the appropriate amount of fertilization to use for their crops. A nondestructive leaf chlorophyll meter is one of the most commonly used devices for performing field assessments of the nutrient status of leaves. However, it is challenging to use a chlorophyll meter to assess the nutritional status of perennial plants, such as the apple (Malus $\times$ domestica) tree, because of the difficulty estimating nitrogen $(\mathrm{N})$ during the entire growing period. We compared the chlorophyll meter readings with leaf nutrient profiles collected from young 'Arisoo'/M.9 apple trees throughout the growing period. A significant positive correlation between the chlorophyll meter readings and leaf $\mathrm{N}$ content was found from May to August during the midseason. Regression analysis indicated that the best sampling time for predicting the foliar $\mathrm{N}$ content of apple tress is from late June to late July. This result suggests that a reliable leaf $\mathrm{N}$ assessment can be performed in a rapid, nondestructive way in apple orchards.

$\mathrm{P}$ lant growth is dependent on its nutrient status. For perennial crop plants, such as apple trees, it is important to assess their nutrient status so that the appropriate content of each nutrient can be balanced during the growing season. Nitrogen is the main component of chlorophyll [Chl (Hák et al., 1993)]; therefore, estimating the plant $\mathrm{N}$ content is important for farmers to determine the amount of $\mathrm{N}$ fertilizer needed for optimum nutrient management, especially for apple trees younger than 5 years (Hák et al., 1993). Foliar $\mathrm{N}$ level is a reliable indicator of tree vigor, which, in turn, affects apple fruit quality as well as floral bud differentiation.

Received for publication 29 Oct. 2019. Accepted for publication 11 Mar. 2019.

Published online 11 April 2019.

Apple Research Institute, National Institute of Horticultural and Herbal Science, Rural Development Administration, 107, Soboangye-ro, Gunwi 39000, South Korea

We gratefully acknowledge financial support from the National Institute of Horticultural and Herbal Sciences Research Program (PJ014241), Apple Research Institute, National Institute of Horticultural and Herbal Sciences, Rural Development Administration.

${ }^{1}$ Corresponding author. E-mail: terra1936@gmail.com.

This is an open access article distributed under the $\mathrm{CC}$ BY-NC-ND license (https://creativecommons.org/ licenses/by-nc-nd/4.0/).

https://doi.org/10.21273/HORTTECH04217-18
In addition, fruit coloration has a negative correlation with foliar $\mathrm{N}$ levels (Fallahi et al., 2001). Because there could be negative consequences of both overfertilization and underfertilization with $\mathrm{N}$, reliable methods of predicting the optimum fertilization levels are needed.

The SPAD-502 (Konica Minolta Sensing, Sakai, Japan) is a leaf chlorophyll meter that has been widely used to estimate foliar $\mathrm{Chl}$ and $\mathrm{N}$ content in a simple, nondestructive way (Ata-Ul-Karim et al., 2016; Markwell et al., 1995). Hereafter, the term SPAD (soil and plant analyzer development) is used to refer to the measured chlorophyll meter readings. Therefore, a correlation between SPAD values and $\mathrm{N}$ content can provide useful information to diagnose the nutrition status of young apple trees.

Arisoo is a new apple cultivar bred in Korea that has been recently planted in many orchards. The purpose of our study was to determine whether the correlation between foliar SPAD values and actual $\mathrm{N}$ content in 'Arisoo' apple trees is strong enough to recommend the use of a chlorophyll meter for field nutritional assessment. Leaf nutrient profiles were established to monitor periodic changes in the content of the following five macronutrients: $\mathrm{N}$, phosphorus $(\mathrm{P})$, potassium $(\mathrm{K})$, calcium $(\mathrm{Ca})$, and magnesium $(\mathrm{Mg})$.

\section{Materials and methods}

Plant Material AND STUdy SITES. 'Arisoo' apple trees were grown for nutritional analysis from Mar. 2016 to Aug. 2018 under field conditions at the Apple Research Institute, Gunwi, Republic of Korea. Twoyear-old 'Arisoo' scions grafted on M.9 rootstocks were planted with spacing of $4 \times 2 \mathrm{~m}$ at three sites. To consider a wide range of leaf chlorophyll and $\mathrm{N}$ levels, three apple orchard sites located in the main apple-producing regions of South Korea [Gunwi (lat. $36.28^{\circ} \mathrm{N}$, long. $128.47^{\circ} \mathrm{E}$ ), Chungju (lat. $37.00^{\circ} \mathrm{N}$, long. $\left.127.88^{\circ} \mathrm{E}\right)$, and Youngcheon (lat. $36.09^{\circ} \mathrm{N}$, long. $128.87^{\circ} \mathrm{E}$ ) ] were classified into three categories of tree vigor (strong, medium, and weak, respectively) depending on soil fertility and the extent of tree growth. Planting density and tree age were the same at the three sites.

SOIL PHYSIOCHEMICAL PROPERTIES. In Apr. 2017, we collected nine soil samples per experimental site by core sampling. Soil was examined from the three depth layers $(0-10,10-20$, and 20-30 cm). Samples were dried for

\begin{tabular}{llll}
\hline $\begin{array}{l}\text { Units } \\
\begin{array}{l}\text { To convert U.S. to SI, } \\
\text { multiply by }\end{array}\end{array}$ & U.S. unit & SI unit & $\begin{array}{l}\text { To convert SI to U.S., } \\
\text { multiply by }\end{array}$ \\
\hline 29.5735 & $\mathrm{fl} \mathrm{oz}$ & $\mathrm{mL}$ & 0.0338 \\
0.3048 & $\mathrm{ft}$ & $\mathrm{m}$ & 3.2808 \\
3.7854 & gal & $\mathrm{L}$ & 0.2642 \\
2.54 & inch $(\mathrm{es})$ & $\mathrm{cm}$ & 0.3937 \\
25.4 & inch $(\mathrm{es})$ & $\mathrm{mm}$ & 0.0394 \\
0.4536 & $\mathrm{lb}$ & $\mathrm{kg}$ & 2.2046 \\
28.3495 & $\mathrm{oz}$ & $\mathrm{g}$ & 0.0353 \\
0.001 & $\mathrm{ppm}$ & $\mathrm{g} \cdot \mathrm{kg}^{-1}$ & 1000 \\
1 & $\mathrm{ppm}$ & $\mathrm{mg} \cdot \mathrm{kg}^{-1}$ & 1 \\
$\left({ }^{\circ} \mathrm{F}-32\right) \div 1.8$ & ${ }^{\circ} \mathrm{F}$ & $\mathrm{o} \mathrm{C}$ & $\left({ }^{\circ} \mathrm{C} \times 1.8\right)+32$ \\
& & &
\end{tabular}


$3 \mathrm{~d}$ and filtered into $1-\mathrm{mm}$ particles ( $1-\mathrm{mm}$ aperture standard testing sieve; Chung Gye Sang Gong Sa, Seoul, Korea). Samples measuring 5 g were placed in flasks and mixed with $20 \mathrm{~mL}$ of Lancaster solution $\{400 \mathrm{~mL}$ acetic acid $+300 \mathrm{~mL} 10 \mathrm{~N}$ lactic acid + $22.2 \mathrm{~g}$ ammonium fluoride $\left(\mathrm{NH}_{4} \mathrm{~F}\right)+$ $170 \mathrm{~g}$ sodium hydroxide $(\mathrm{NaOH})+$ $133.3 \mathrm{~g}$ ammonium sulfate $\left.\left[\left(\mathrm{NH}_{4}\right)_{2} \mathrm{SO}_{4}\right]\right\}$ from a 20 -L solution with a $\mathrm{pH}$ of 4.25 for $\mathrm{P}$ analysis, or with $50 \mathrm{~mL}$ of ammonium acetate solution ( $\mathrm{pH} 7$ ) for $\mathrm{K}, \mathrm{Ca}$, and $\mathrm{Mg}$ analyses. After filtering the solution (No. 6 filter paper; Whatman, Little Chalfont, UK), we measured the content of the four macronutrients, $\mathrm{P}, \mathrm{K}, \mathrm{Ca}$, and $\mathrm{Mg}$, using inductively coupled plasma spectrometry (Integra XL 2.6; GBC Scientific Equipment, Melbourne, Australia) as described previously (Kim et al., 2011). $\mathrm{N}$ was determined using a Kjeldahl nitrogen analyzer (Kjeltec 8400; Foss, Hägersten, Sweden); $1 \mathrm{~g}$ of soil filtered with a $0.5-\mathrm{mm}$ sieve was dissolved in $12 \mathrm{~mL}$ of sulfuric acid solution and heated for the digestion process with two catalyst accelerators $[5 \mathrm{~g}$ potassium sulfate $\left(\mathrm{K}_{2} \mathrm{SO}_{4}\right)+0.5 \mathrm{~g}$ copper sulfate monohydrate $\left(\mathrm{CuSO}_{4} \cdot \mathrm{H}_{2} \mathrm{O}\right) \quad(1000$ Kjeltabs CX; Foss)]. To determine soil organic matter $(\mathrm{OM})$, soil samples were dissolved in $0.2 \mathrm{M}$ potassium dichromate $\left(\mathrm{K}_{2} \mathrm{Cr}_{2} \mathrm{O}_{7}\right)$ solution with sulfuric acid solution and heated for $5 \mathrm{~min}$. After oxidation, excess dichromate was determined by titration with ammonium ferrous sulfate $\left[\mathrm{Fe}\left(\mathrm{NH}_{4}\right)_{2}\left(\mathrm{SO}_{4}\right)_{2} \cdot 6 \mathrm{H}_{2} \mathrm{O}\right]$. The OM content was calculated as described previously (Lee and Zhang, 2011). Soil $\mathrm{pH}$ and electrical conductivity (EC) were measured with a $\mathrm{pH} / \mathrm{EC}$ meter (915PDC; Istek, Seoul, Korea) using a $1: 5(\mathrm{w} / \mathrm{v})$ dilution method (Lee and Zhang, 2011).

SPAD READINGS. In 2017 and 2018, leaf samples were collected from each site for the SPAD reading analysis. Leaf samples collected in 2017 were used to determine the leaf nutrient profiles and to perform an analysis of the correlation matrix, whereas samples collected in 2018 were used for $\mathrm{N}$ regression analyses. We measured SPAD values at different time points from late May to late August. To minimize variability among leaves, we measured a uniform leaf section of all leaves used for the experiment. The middle leaf section between the top and bottom adaxial sides was selected from the third to the twelfth midshoot position of l-year-old new shoots and sampled from each side of the tree at a height of 1-2 m for 72 randomly selected 3 -year-old 'Arisoo' apple trees. Ten leaves were sampled from each tree, and the SPAD readings from each leaf were recorded and averaged to match the foliar macronutrient $(\mathrm{N}, \mathrm{P}$, $\mathrm{K}, \mathrm{Ca}$, and $\mathrm{Mg}$ ) content for statistical analysis.

LEAF NUTRIENT CONTENT. Leaf samples collected at each sampling timepoint during each growing period were dried for $3 \mathrm{~d}$ and then ground; $0.4 \mathrm{~g}$ of each ground sample was dissolved in $12 \mathrm{~mL}$ of sulfuric acid solution with two catalyst accelerators $\left[3.5 \mathrm{~g} \mathrm{~K}_{2} \mathrm{SO}_{4}+3.5 \mathrm{mg}\right.$ selenium (1000 Kjeltabs S/3.5; Foss)]. The solution was heated on a heating plate at $420{ }^{\circ} \mathrm{C}$ for $\mathrm{l} \mathrm{h}$ and cooled before the Kjeldahl digestion method was performed (Morikawa et al., 2004).

Table 1. Soil properties at the three experimental sites in South Korea: Youngcheon (site A), Gunwi (site B), and Chungju (site C). Samples from a soil depth of 0 to $30 \mathrm{~cm}$ were analyzed. Properties of top soil $(0-10 \mathrm{~cm})$ and soil nitrogen of two depth layers (0-10 and 10-20 cm) were compared among sites.

\begin{tabular}{|c|c|c|c|c|c|c|c|c|}
\hline Location & $\begin{array}{l}\text { Depth } \\
(\mathrm{cm})^{\mathrm{z}}\end{array}$ & $\mathrm{pH}^{\mathrm{y}}$ & $\begin{array}{l}\text { Organic matter } \\
\left(\mathrm{g} \cdot \mathrm{kg}^{-1}\right)^{\mathrm{z}}\end{array}$ & $\begin{array}{c}\text { Nitrogen } \\
(\%)\end{array}$ & $\begin{array}{l}\text { Phosphorus } \\
\left(\mathrm{mg} \cdot \mathrm{kg}^{-1}\right)^{\mathrm{z}}\end{array}$ & $\begin{array}{c}\text { Potassium } \\
\left(\mathrm{cmol} \cdot \mathrm{kg}^{-1}\right)^{\mathrm{z}}\end{array}$ & $\begin{array}{c}\text { Calcium } \\
\left(\mathrm{cmol} \cdot \mathrm{kg}^{-1}\right)\end{array}$ & $\begin{array}{l}\text { Magnesium } \\
\left(\mathrm{cmol} \cdot \mathrm{kg}^{-1}\right)\end{array}$ \\
\hline \multirow[t]{3}{*}{ A } & $10^{x}$ & $6.8 \mathrm{~b}^{\mathrm{w}}$ & $31.8 \mathrm{a}$ & $0.20 \mathrm{a}$ & $984.9 \mathrm{a}$ & $0.90 \mathrm{a}$ & $10.13 \mathrm{a}$ & $1.52 \mathrm{c}$ \\
\hline & 20 & 6.6 & 26.5 & 0.13 & 966.7 & 0.67 & 8.48 & 1.31 \\
\hline & 30 & 7.0 & 20.5 & 0.10 & 616.6 & 0.64 & 8.12 & 1.36 \\
\hline \multirow[t]{2}{*}{ B } & 10 & $7.1 \mathrm{a}$ & $17.8 \mathrm{~b}$ & $0.12 \mathrm{~b}$ & $395.4 \mathrm{~b}$ & $0.26 \mathrm{~b}$ & $8.16 \mathrm{~b}$ & $2.11 \mathrm{~b}$ \\
\hline & 20 & 7.0 & 19.0 & 0.13 & 356.7 & 0.28 & 8.07 & 2.14 \\
\hline & 20 & 6.9 & 18.7 & 0.09 & 324.3 & 0.15 & 6.87 & 2.71 \\
\hline & 30 & 6.9 & 23.2 & 0.11 & 366.1 & 0.17 & 7.45 & 2.97 \\
\hline
\end{tabular}

${ }^{\mathrm{z}} 1 \mathrm{~cm}=0.3937 \mathrm{inch} ; \mathrm{l} \mathrm{g} \cdot \mathrm{kg}^{-1}=1000 \mathrm{ppm} ; \mathrm{l} \mathrm{mg} \cdot \mathrm{kg}^{-1}=1 \mathrm{ppm} ; \mathrm{l} \mathrm{kg}=2.2046 \mathrm{lb}$.

${ }^{\mathrm{y}} \mathrm{Soil} \mathrm{pH}$ was determined in the $1: 5(\mathrm{w} / \mathrm{v})$ soil-to-water mass ratio.

${ }^{\mathrm{x}}$ Soil nitrogen differences in two depth layers $(0-10 \mathrm{~cm}$ and $10-20 \mathrm{~cm})$ among sites were $\mathrm{A}=0.17 \mathrm{a}, \mathrm{B}=0.12 \mathrm{~b}$, and $\mathrm{C}=0.10 \mathrm{c}$ according to Duncan's multiple range test (DMRT) at $P<0.05$.

${ }^{\text {w } M e a n s ~ w i t h i n ~ t h e ~ s a m e ~ c o l u m n ~ f o l l o w e d ~ b y ~ t h e ~ s a m e ~ l e t t e r ~ d o ~ n o t ~ d i f f e r ~ s t a t i s t i c a l l y ~ b a s e d ~ o n ~ t h e ~ D M R T ~ a t ~} P<0.05$.

Table 2. Tree vigor at the three experimental sites in South Korea: Youngcheon (site A), Gunwi (site B), and Chungju (site C). Tree vigor properties of 3-year-old 'Arisoo' apple trees, including tree height, width, stem diameter, growth of both new shoots and lateral branches were compared among sites.

\begin{tabular}{lccccccc}
\hline Tree vigor & Location & $\begin{array}{c}\text { Tree ht } \\
(\mathbf{c m})^{\mathrm{z}}\end{array}$ & $\begin{array}{c}\text { Tree } \\
\text { width }(\mathrm{cm})\end{array}$ & $\begin{array}{c}\text { Stem } \\
\text { diam }(\mathbf{m m})^{\mathrm{z}}\end{array}$ & $\begin{array}{c}\text { Avg lateral branch } \\
\text { length }(\mathbf{c m})\end{array}$ & $\begin{array}{c}\text { Avg new shoot } \\
\text { length }(\mathbf{c m})\end{array}$ & $\begin{array}{c}\text { Total new shoot } \\
\text { length }(\mathbf{c m})\end{array}$ \\
\hline Strong & $\mathrm{A}$ & $320 \mathrm{a}^{\mathrm{y}}$ & $177.7 \mathrm{a}$ & $37.2 \mathrm{a}$ & $104.2 \mathrm{a}$ & $17.1 \mathrm{a}$ & 9,112 \\
Medium & $\mathrm{B}$ & $297.8 \mathrm{~b}$ & $168.4 \mathrm{a}$ & $30.6 \mathrm{~b}$ & $104.6 \mathrm{a}$ & $15.1 \mathrm{~b}$ & 7,462 \\
Weak & $\mathrm{C}$ & $265.6 \mathrm{c}$ & $166.8 \mathrm{a}$ & $31.6 \mathrm{~b}$ & $84.7 \mathrm{a}$ & $8.9 \mathrm{c}$ & 3,276 \\
\hline
\end{tabular}

${ }^{\mathrm{z}} \mathrm{l} \mathrm{cm}=0.3937$ inch; $1 \mathrm{~mm}=0.0394$ inch

${ }^{\mathrm{y}}$ Means within the same column followed by the same letter do not differ statistically based on the Duncan's multiple range test $(P<0.05)$. 
To detect the four main macronutrients $(\mathrm{P}, \mathrm{K}, \mathrm{Ca}$, and $\mathrm{Mg}), \mathrm{l} \mathrm{g}$ of each ground leaf sample was dissolved in $10 \mathrm{~mL}$ of plant digestive solution (10

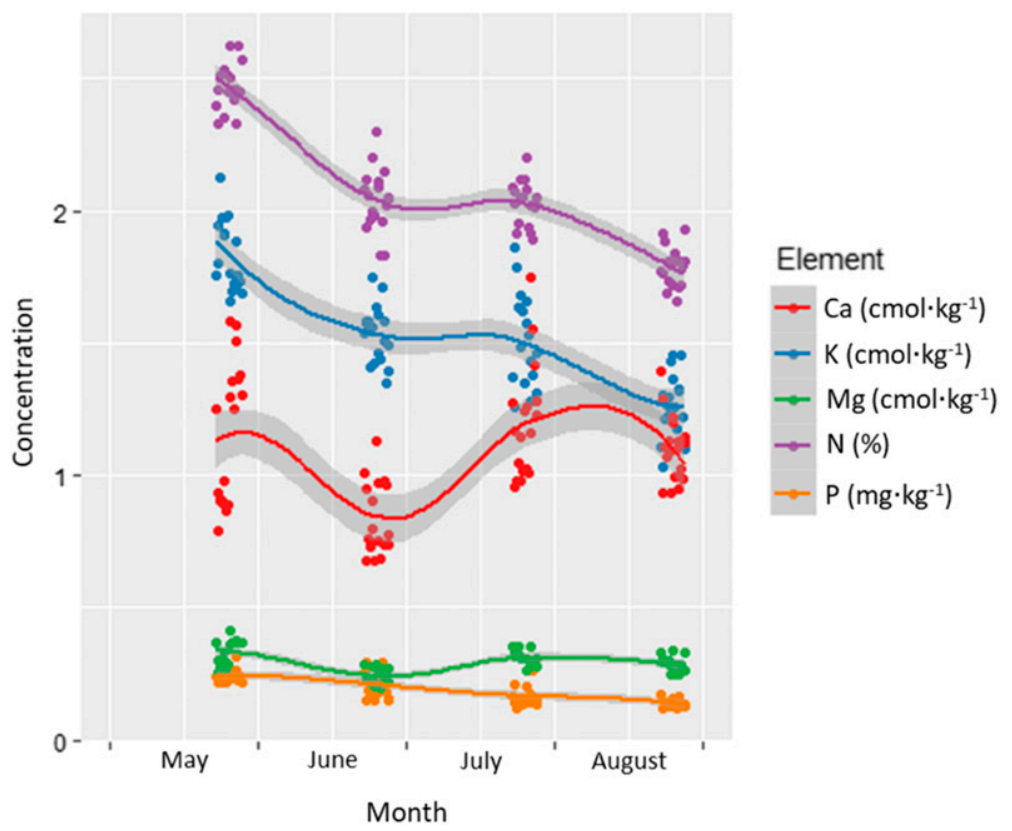

Fig. 1. Leaf nutrient profile during the growing period (May-August). Two hundred sixteen leaf samples of 3-year-old 'Arisoo' /M.9 apple trees were collected in 2017 from three experimental plots in Korea [Youngcheon (lat. $36.09^{\circ} \mathrm{N}$, long. $128.87^{\circ} \mathrm{E}$ ), Gunwi (lat. $36.28^{\circ} \mathrm{N}$, long. $128.47^{\circ} \mathrm{E}$ ), and Chungju (lat. $37.00^{\circ} \mathrm{N}$, long. $\left.\left.127.88^{\circ} \mathrm{E}\right)\right]$ and analyzed to document nutrient profiles of macronutrients, including nitrogen $(\mathrm{N})$, phosphorus $(\mathrm{P})$, potassium $(\mathrm{K})$, calcium $(\mathrm{Ca})$, and magnesium (Mg). The $95 \%$ confidence interval is indicated by gray, along with the average trend line of each macronutrient $\left(1 \mathrm{mg} \cdot \mathrm{kg}^{-1}=1 \mathrm{ppm}, 1 \mathrm{~kg}=2.2046 \mathrm{lb}\right)$. peak absorption ( $\mathrm{P}$ at $213.618 \mathrm{~nm}$ wavelength, $\mathrm{K}$ at $769.896 \mathrm{~nm}$ wavelength, Ca at $317.933 \mathrm{~nm}$ wavelength, and $\mathrm{Mg}$ at $285.213 \mathrm{~nm}$ wavelength), and the actual content was converted from 100-fold diluted nutrient extracts (Integra XL 2.6; GBC Scientific Equipment).

Leaf Chl content. A total of 42 leaf samples were analyzed. Six 11$\mathrm{mm}$-diameter disks from each leaf were placed in the same falcon tube (BD Falcon, Bedford, MA) and mixed with $10 \mathrm{~mL}$ methanol $(\mathrm{MeOH})$ for $\mathrm{Chl}$ extraction. Mixtures were incubated in the dark for $16 \mathrm{~h}$ at $4{ }^{\circ} \mathrm{C}$. We measured leaf Chl content with a spectrophotometer (Epoch 2; Biotek, Winooski, VT) as described previously (Porra et al., 1989). Total chlorophyll (Ct) content was calculated $(\mathrm{Ct}=\mathrm{Chl}$ $\mathrm{a}+\mathrm{Chl} \mathrm{b}$ ) using the absorbance of $\mathrm{Chl}$ (Chl a: 663 and $645 \mathrm{~nm}$ wavelength; Chl b: 645 and $652 \mathrm{~nm}$ wavelength).

Tree GROWTH AND VIGOR. In Oct. 2017, we measured the growth characteristics of 3-year-old trees at each site, including tree height, tree width, stem diameter, and growth of lateral branches, as well as the growth of new shoots, which together reflect tree vigor. Stem diameter was measured with digital calipers (model 500; Mitutoyo Corp., Kawasaki, Japan) at $10 \mathrm{~cm}$ above the grafted junction of each tree. Tree height was measured
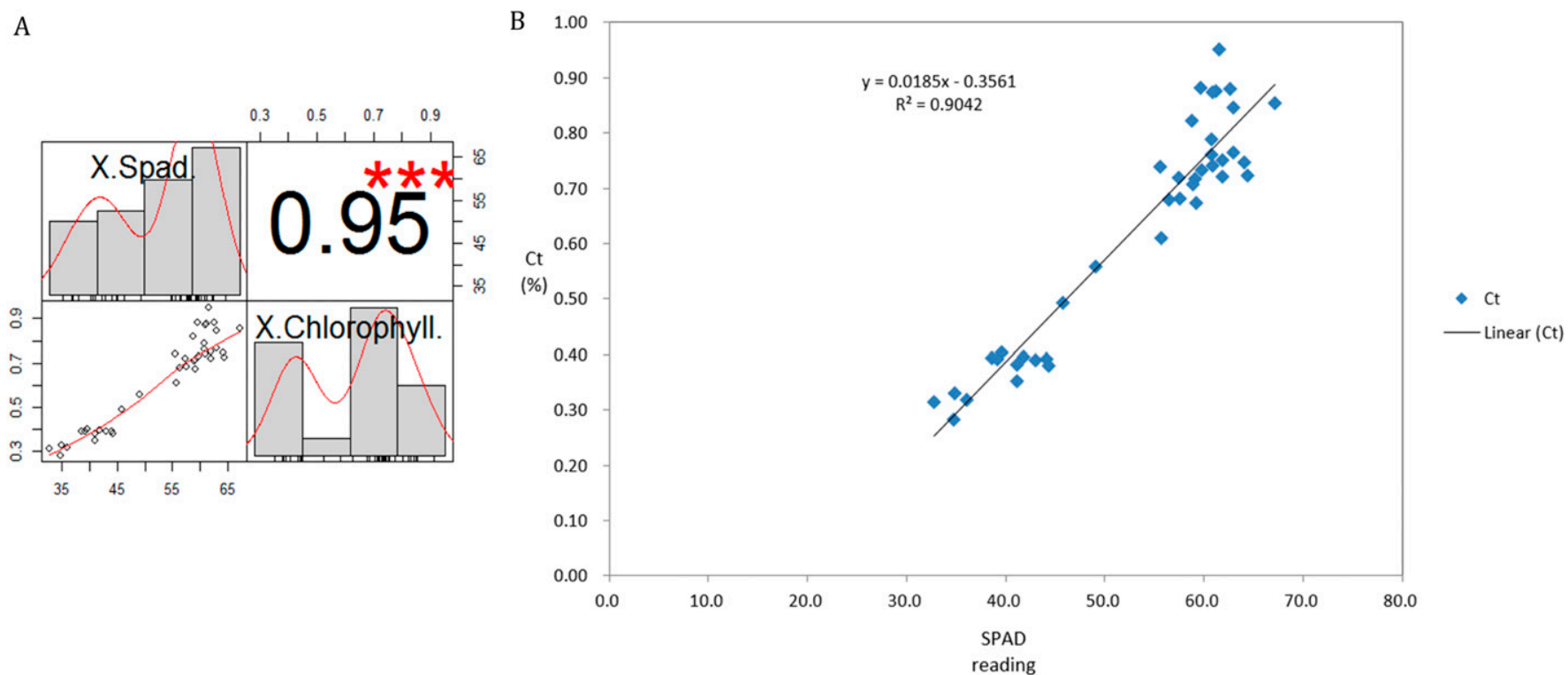

Fig. 2. (A) Correlation between leaf chlorophyll content and chlorophyll meter (SPAD) reading of 'Arisoo'/M.9 apple leaves in 2017. Total chlorophyll $(\mathrm{Ct}=$ chlorophyll a + chlorophyll $\mathrm{b})$ showed a high and positive correlation with the SPAD reading $(r=0.95)$. (B) Regression model for leaf chlorophyll estimation using the SPAD reading. The linear regression model was $y=$ $0.0185 \mathrm{x}-0.3561\left[\mathrm{y}=\mathrm{Ct}, \mathrm{x}=\mathrm{SPAD}\right.$ reading $\left.\left(R^{2}=0.9042\right)\right]$. 
with a height meter (KAl3; Kyelim, Daegu, Korea). Tree width and length of both lateral branches and new shoots were measured with measuring tapes (KMC-86; Komelon, Busan, Korea).
Data analysis AND statistics. Differences in chemical properties and tree vigor of 3-year-old 'Arisoo' / M.9 apple trees in different experimental topsoil locations $(0-10 \mathrm{~cm})$ were determined with Duncan's multiple range test (DMRT). Using R library packages Perform Analysis and Corrplot (Studio version 3.5.0; RStudio, Boston, MA), we tested the
May

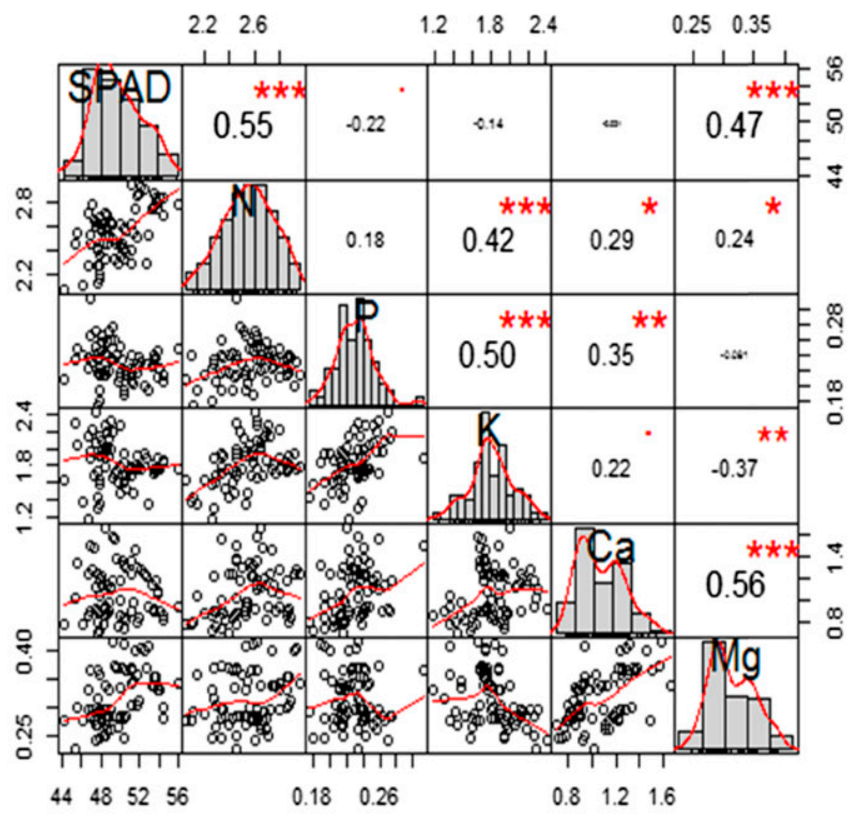

July



June

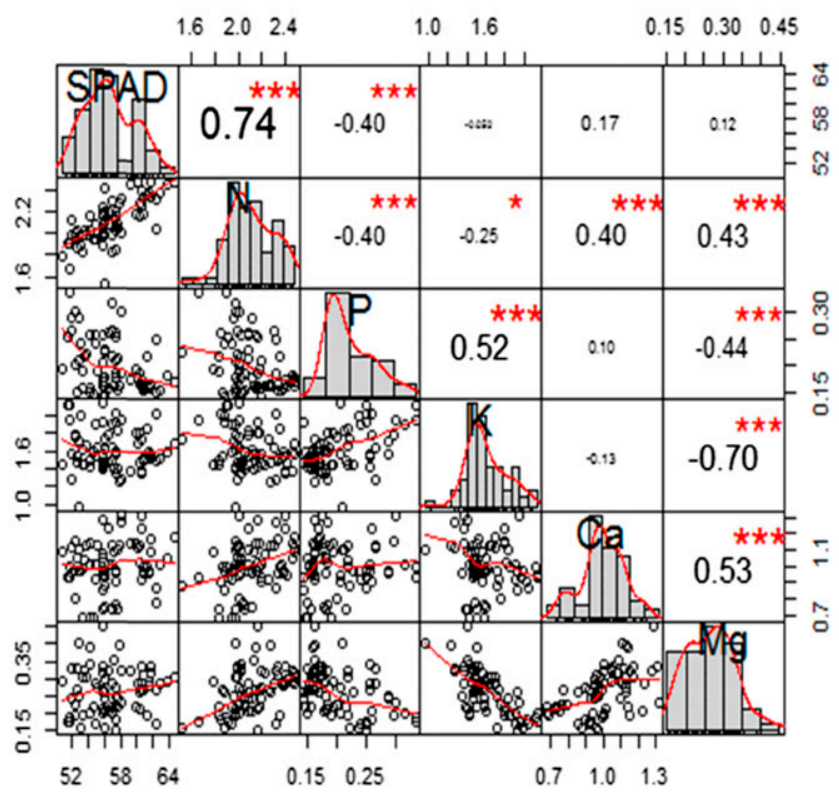

August

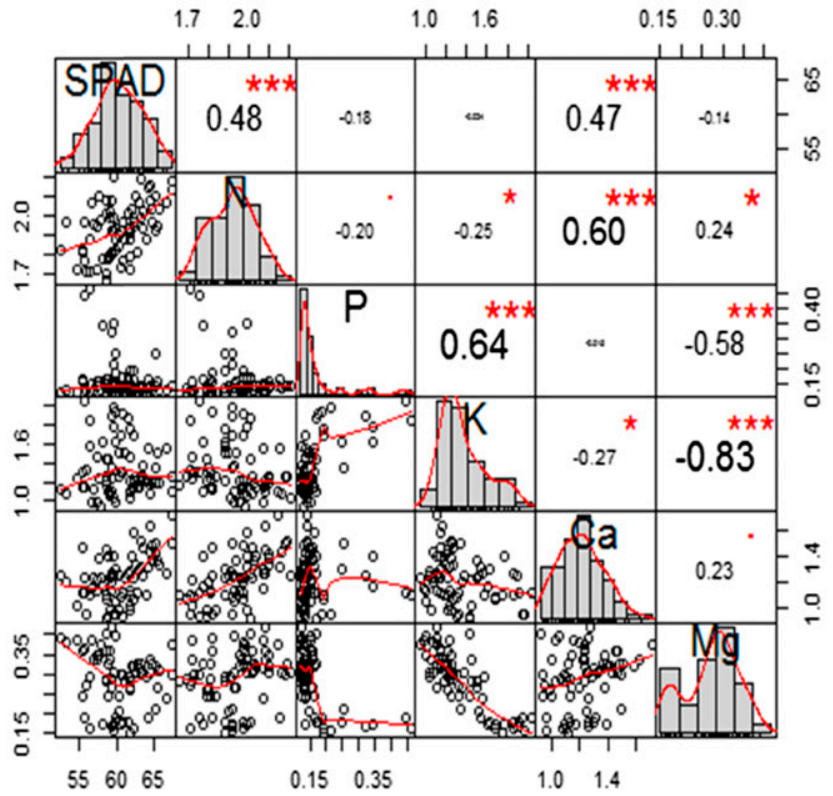

Fig. 3. Correlation matrix of chlorophyll meter (SPAD) readings of five macronutrients, including nitrogen (N), phosphorus $(\mathrm{P})$, potassium $(\mathrm{K})$, calcium $(\mathrm{Ca})$, and magnesium $(\mathrm{Mg})$, using a random leaf sampling method for 'Arisoo'/M.9 apple trees in 2017. Scatter plot matrix during the growing season (May-August) shows the relationship with SPAD among nutrients. The correlation coefficient is flagged with red stars based on the $P$ value at the top right corner $\left({ }^{*},{ }^{* *},{ }^{* *}=P<0.05,0.01\right.$, or $\mathbf{0 . 0 0 1}$, respectively). The distribution of values is shown at the bottom left with a moving average trend line (red). Only $\mathrm{N}$ showed a significant and positive relationship with SPAD readings for all sampling timepoints during the growing period. 
correlation between SPAD readings and analytically determined leaf nutrients. For SPAD-N regression modeling, SPAD readings were performed in triplicate and matched to actual foliar $\mathrm{N}$ content. We performed SPAD-N prediction and fit test validation using $\mathrm{R}$ programming (GGplot2 library; RStudio).

\section{Results}

SOIL PROPERTIES AND LEAF NUTRIENT PROFILES OF 'ARISOO' / M.9 APPLE TREES DURING THE GROWING SEASON. We compared soil nutrient characteristics among the experimental sites using DMRT with a significance level of $P<0.05$ ( $\mathrm{R}$ package agricolae; RStudio). As shown in Table 1 , there was a significant difference in $\mathrm{P}, \mathrm{Ca}$, and $\mathrm{Mg}$ among groups. Analysis of topsoil $(0-10 \mathrm{~cm}$ depth) showed that both soil OM and $\mathrm{N}$ content were higher at Youngcheon (site A), with both Gunwi (site B) and Chungju (site C) showing similar lower values. Site $A$ also had the most vigorous trees. Soil OM content was closely related to soil $\mathrm{N}$ availability for plants (Sahrawat, 2006). There was a significant difference in soil $\mathrm{N}$ when the data for $10-20 \mathrm{~cm}$ were combined with data for $0-10 \mathrm{~cm}$ during DMRT comparisons among sites ( site $\mathrm{A}=0.17$, site $\mathrm{B}=$ 0.12 , and site $\mathrm{C}=0.10$ ) (Table 1 ). Differences in tree vigor corresponded with differences in soil data (Table 2) because the relation between the tree vigor gradient and soil nutrition provided reasons to perform further leaf sampling and nutritional analyses using the chlorophyll meter.

Leaf nutrient profiling (Fig. 1) indicated that the highest foliar $\mathrm{N}$ levels in May gradually decreased throughout the remainder of the studied growth period. Similarly, $P$ and $K$ were highest in May and decreased thereafter. However, the trend line of Ca levels appeared to be lowest in June and slightly increased in July, but there were too many monthly variations in $\mathrm{Ca}$ distribution. In contrast, $\mathrm{Mg}$ levels remained relatively low compared with those of other nutrients throughout the growing season.

A


B


Fig. 4. Statistical analysis of regression modeling using the chlorophyll meter (SPAD) readings and leaf nitrogen (N) in June 2018 (A) and July 2018 (B) of 4-year-old 'Arisoo'/M.9 apple trees. The correlation coefficient and distribution of both SPAD and $\mathrm{N}$ values are shown on the left side. The correlation was much stronger in June (A) than in July (B). Linear regression models for $\mathrm{N}$ in June $\left[\mathrm{y}=0.0314 \mathrm{x}+0.3323\left(R^{2}=0.822\right)\right]$ and July $\left[\mathrm{y}=0.0307 \mathrm{x}+0.1786\left(R^{2}=0.7359\right)\right]$ are shown on the right side (ggplot2 library from $R$ package, $R$ Studio version 3.5.0; RStudio, Boston, MA). 
SPAD READING CHANGES IN PATTERNS AND FOLIAR N CONTENT DURING THE GROWING SEASON. SPAD values reflect leaf Chl content (Uddling et al., 2007). Before using the chlorophyll meter to measure leaf $\mathrm{Chl}$ content, we verified the relationship between the chlorophyll meter readings and actual leaf $\mathrm{Chl}$ content (Fig. 2).

SPAD readings were positively and highly related to Ct content $(r=$ $0.95)$ (Fig. 2A). Linear regression analysis showed that individual leaf $\mathrm{Chl}$ content can be reliably predicted using the SPAD reading (Fig. 2B), which explained how SPAD readings can be an accurate indication of leaf Chl content of 'Arisoo' apple tree leaves.

Based on these findings, we performed an analysis of the correlation matrix of leaf nutrients and SPAD readings using random leaf sampling (Fig. 3). Consistent with the results of previous studies of other crops [rice (Oryza sativa), hardwood trees, and maize (Zea mays)] (Ata-Ul-Karim et al., 2016; Chang and Robison, 2003; Costa et al., 2001), SPAD readings were significantly correlated with the $\mathrm{N}$ content of apple leaves at all sampling timepoints. A previous study reported that the relationship between SPAD readings and leaf $\mathrm{N}$ status varied among apple cultivars as well as with sampling times (Neilsen et al., 1995). The scatter plot matrix in Fig. 3 shows that leaf $\mathrm{N}$ levels had a strong correlation with SPAD readings from late June to July, but that the correlation decreased in May and August. These results indicated that the optimum sampling timepoint for assessing leaf $\mathrm{N}$ levels was between late June and late July. Therefore, to obtain calibration data, we collected leaf samples with a wide range of leaf $\mathrm{Chl}$ and $\mathrm{N}$ pools in June and July.

Regression ANALYSIS AND GOODNESS-OF-FIT TEST OF THE SPAD-N MODEL. We measured the SPAD readings and foliar $\mathrm{N}$ content of 4-year-old 'Arisoo' apple trees leaves with a wide range of Chl pools. A significant and much higher correlation coefficient resulted compared with that indicated by the previous correlation data $(r=0.91$ in June; $r=$ 0.85 in July) (Fig. 4). Linear regression models for assessing leaf $\mathrm{N}$ were $\mathrm{y}=0.0314 \mathrm{x}+0.3323\left(R^{2}=0.822\right)$ in June and $\mathrm{y}=0.0307 \mathrm{x}+0.1786\left(R^{2}=\right.$ $0.7359)$ in July.
A



B
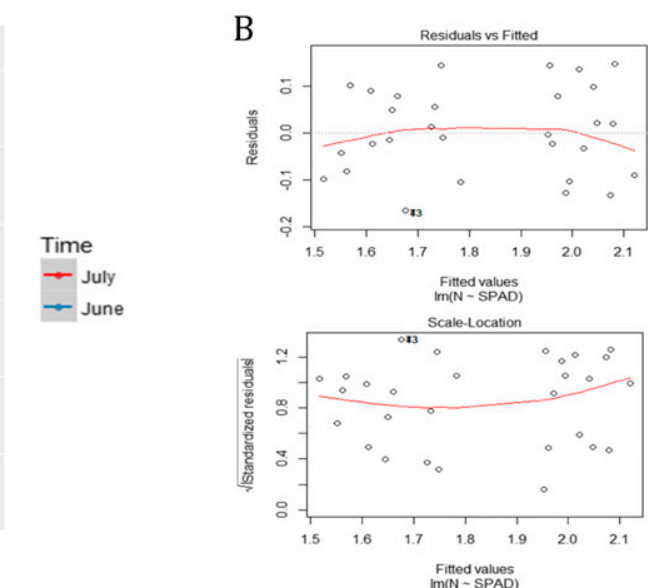

C
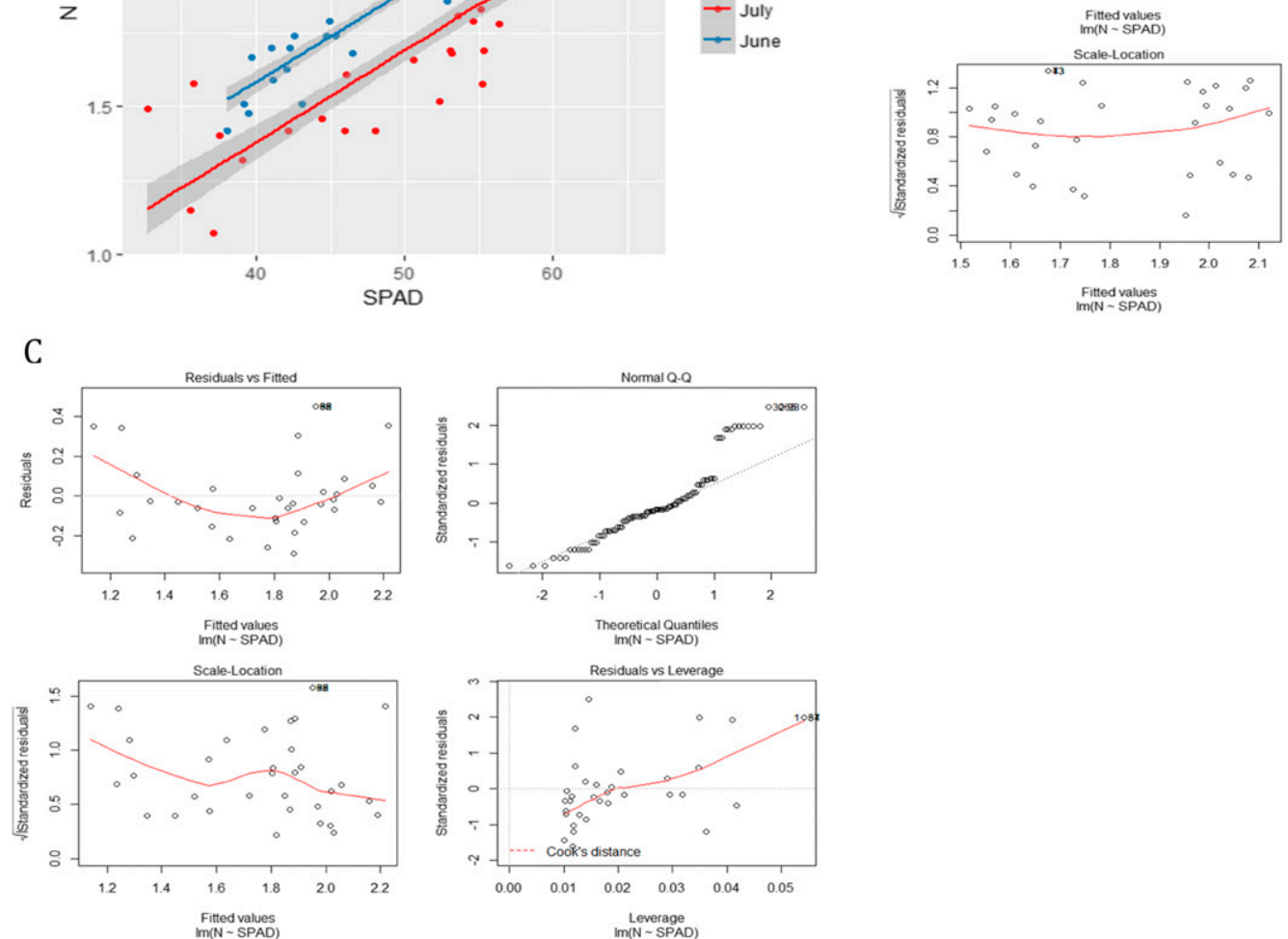
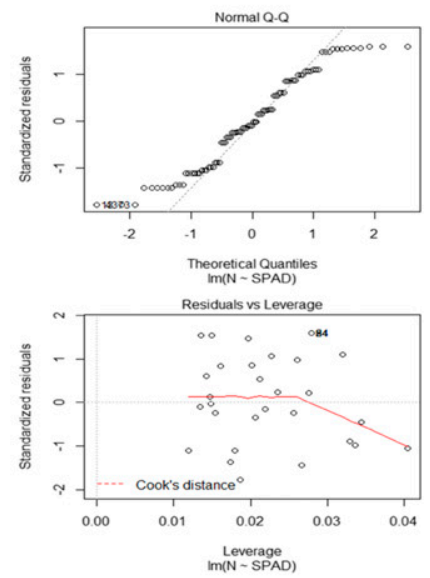

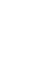


To validate each leaf $\mathrm{N}$ regression model, we performed a fit test validation. A 95\% fit plot result showed that the data were more scattered during July than during June (Fig. 5A), indicating that the leaf $\mathrm{N}$ regression model showed a relatively better fit in June than it did in July. As shown in the plot of residuals vs. the fitted plot, the maximum residual value in June was smaller than that in July, and the residual distribution was more widely scattered $(-0.4$ to +0.4$)$ in July (Fig. 5C), whereas the residual distribution was less scattered $(-0.2$ to +0.2$)$ in June (Fig. 5B). Specifically, the average trend line from the model in June was close to 0 , which was almost parallel to fitted values ( $\mathrm{x}$-axis). However, both regression models had a small range of leverage values, which were all less than 0.05 . Therefore, we concluded that the best time to assess leaf $\mathrm{N}$ of 'Arisoo' apple trees using the chlorophyll meter is late June.

\section{Discussion}

In this study, we aimed to establish the nutritional assessment model for 'Arisoo' apple leaves. We found that there were positive relationships between SPAD readings and leaf $\mathrm{N}$ content in June and July. The correlation coefficient in July was $r=0.85$, which was still highly positive. The fit test validation results of the July model (Fig. 5C) indicated that leverage points more than 0.05 might have contributed to distortion of the line. In addition, there were points at the end of the line in the normal $\mathrm{Q}-\mathrm{Q}$ plot that influenced the accuracy of the July regression model. Fit results for July might be improved with further correction of the data. During the growing period that was studied, there was an inconsistent correlation between the leaf $\mathrm{Chl}$ and $\mathrm{N}$ content. 'Arisoo' apple, which is a midharvest cultivar, has a unique leaf structure compared with that of other cultivars. The variations in leaf morphology of different apple cultivars could affect chlorophyll meter estimations and their correlation with leaf $\mathrm{N}$ levels. Therefore, previous studies have reported that leaf thickness influenced the accuracy of Chl estimation obtained using the SPAD reading (Campbell et al., 1990; Marenco et al., 2009). We compared three different leaves from scion cultivars
Fuji, Hongro, and Arisoo (Fig. 6). Light transmission might be challenging with a thicker leaf structure (Fig. 6A) compared with light transmission of leaves that are not as thick (Fig. 6B and C). When the light source from the chlorophyll meter goes through the leaf surface, the irregular abaxial layer of 'Arisoo' / M.9 leaves might cause a scattering effect with light diffraction, which could result in miscalculation of the actual leaf Chl content. Because a previous study showed that the cuticle wax layer tends to become much thicker during the later period of growth (Fernández et al., 2016), the unique leaf properties of 'Arisoo' apple may explain the inconsistent correlation observed between SPAD readings and the actual leaf $\mathrm{Chl}$ content.

The correlation matrix revealed that among the five macronutrients analyzed, a significant positive relationship was observed only between SPAD readings and $\mathrm{N}$ content at all sampling timepoints during the growth period studied. Notably, the value of SPAD readings increased in late summer, whereas that of foliar $\mathrm{N}$ content decreased, indicating that the

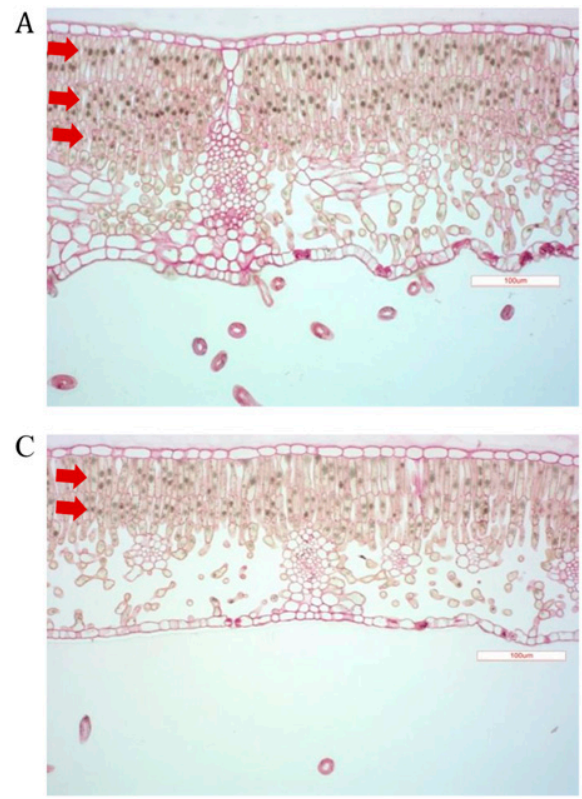

Fig. 6. Leaf morphological differences as shown by a microscopic image comparison among three apple cultivars: (A) Arisoo, (B) Fuji, and (C) Hongro. Leaf polarity thickness, extra palisade layer, differences in leaf thickness, cell density of sponge mesophyll tissue, and stomatal distribution are shown. Sponge mesophyll cell layers are marked with red arrows. (D) Leaf structure images of the adaxial (top) and abaxial (bottom) sides of the three cultivars: Arisoo (left), Fuji (middle), and Hongro (right).



correlation becomes weak during the earlier and later stages of growth. Altogether, our results suggest that the chlorophyll meter can be used to measure $\mathrm{N}$ content in young 'Arisoo' apple leaves, but low SPAD-N correlation and its inconsistency with time should be explained to diagnose leaf nutrient status effectively. A comparison of leaf tissue layers from 'Arisoo' with that of other cultivars might explain the inconsistency in the SPAD-N relationship, but the physiological processes occurring toward the end of the growing season need to be further investigated.

Among the five major leaf macronutrients from 'Arisoo' /M.9 apple trees that were analyzed, leaf $\mathrm{N}$ was most strongly associated with SPAD readings during the studied growth period. A regression analysis indicated that the best sampling timepoint for accurate prediction of apple foliar $\mathrm{N}$ levels is from late June to late July. Therefore, leaf $\mathrm{N}$ assessments may be performed in a fast, reliable, nondestructive way in apple orchards. However, the inconsistency in the the growing season requires further investigation.

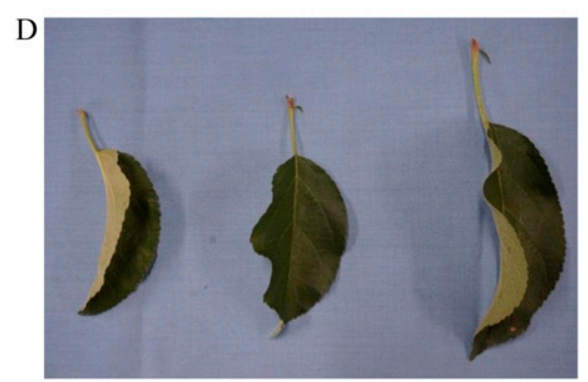
high correlation toward the end of 


\section{Literature cited}

Ata-Ul-Karim, S.T., Q. Cao, Y. Zhu, L. Tang, M.I.A. Rehmani, and W. Cao. 2016. Non-destructive assessment of plant nitrogen parameters using leaf chlorophyll measurements in rice. Front. Plant Sci. 7:1829.

Campbell, R.J., K.N. Mobley, R.P. Marini, and D.G. Pfeiffer. 1990. Growing conditions alter the relationship between SPAD501 values and apple leaf chlorophyll. HortScience 25:330-331.

Chang, S.X. and D.J. Robison. 2003. Nondestructive and rapid estimation of hardwood foliar nitrogen status using the SPAD-502 chlorophyll meter. For. Ecol. Mgt. 181:331-338.

Costa, C., L.M. Dwyer, P. Dutilleul, D.W. Stewart, B.L. Ma, and D.L. Smith. 2001. Inter-relationships of applied nitrogen, SPAD, and yield of leafy and non-leafy maize genotypes. J. Plant Nutr. 24:1173-1194.

Fallahi, E., W.M. Colt, and B. Fallahi. 2001. Optimum ranges of leaf nitrogen for yield, fruit quality, and photosynthesis in 'BC-2 Fuji' apple. J. Amer. Pomol. Soc. 55(2):68.

Fernández, V., P. Guzmán-Delgado, J. Graça, S. Santos, and L. Gil. 2016. Cuticle structure in relation to chemical composition: Re-assessing the prevailing model. Front. Plant Sci. 7:427.

Hák, R., U. Rinderle-Zimmer, H.K. Lichtenthaler, and L. Natr. 1993. Chlorophyll a fluorescence signatures of nitrogen deficient barley leaves. Photosynthetica 28:151-159.

Kim, M.S., S.B. Lee, Y.H. Kim, S.S. Kang, B.K. Hyun, H.Y. Gong, and S.K. Ha. 2011. Influence of sea water treatment on soil chemical properties and contents of inorganic elements in garlic. Korean J. Soil Sci. Fert. 44:1295-1299.

Lee, Y.H. and Y.S. Zhang. 2011. Response of microbe to chemical properties from orchard soil in Gyeongnam province. Korean J. Soil Sci. Fert. 44(2):236241.

Marenco, R.A., S.A. Antezana-Vera, and H.C.S. Nascimento. 2009. Relationship between specific leaf area, leaf thickness, leaf water content and SPAD-502 readings in six Amazonian tree species. Photosynthetica 47:184-190.

Markwell, J., J.C. Osterman, and J.L. Mitchell. 1995. Calibration of the Minolta SPAD-502 leaf chlorophyll meter. Photosynth. Res. 46:467-472.
Morikawa, H., M. Takahashi, A. Sakamoto, T. Matsubara, G.I. Arimura, Y. Kawamura, K. Fukunaga, K. Fujita, N. Sakurai, T. Hirata, and H. Ide. 2004. Formation of unidentified nitrogen in plants: An implication for a novel nitrogen metabolism. Planta 219:14-22.

Neilsen, D., E.J. Hogue, G.H. Neilsen, and P. Parchomchuk. 1995. Using SPAD-502 values to assess the nitrogen status of apple trees. HortScience 30: 508-512.

Porra, R.J., W.A. Thompson, and P.E. Kriedemann. 1989. Determination of accurate extinction coefficients and simultaneous equations for assaying chlorophylls $a$ and $b$ extracted with four different solvents: Verification of the concentration of chlorophyll standards by atomic absorption spectroscopy. Biochim. Biophys. Acta 975:384-394.

Sahrawat, K.L. 2006. Organic matter and mineralizable nitrogen relationships in wetland rice soils. Commun. Soil Sci. Plant Anal. 37:787-796.

Uddling, J., J. Gelang-Alfredsson, K. Piikki, and H. Pleijel. 2007. Evaluating the relationship between leaf chlorophyll concentration and SPAD-502 chlorophyll meter readings. Photosynth. Res. 91:37-46. 